\title{
Physicochemical and Technological Studies on Volkamer Lemon Fruit (Citrus volkameriana)
}

\author{
Dalia H. Eshra' ${ }^{1}$, Reda A. Aamer ${ }^{2}$ \& Abdel-Nabey A. A. ${ }^{1}$ \\ 1 Food Science and Technology Dept.- Fac. of Agric., Alex. Univ., El Shatby 21545, Alexandria - \\ Egypt. \\ 2 Hort. Crop Technology Res. Department- Food Technology Research Institute- A.R.C.- Egypt. \\ Received: 17 February, 2020 \\ Revised: 26 April, 2020 \\ Accepted: 6 May, 2020
}

\begin{abstract}
No attention has been made to evaluate the physicochemical and technological properties of volkamer lemon fruit (VLF). Thus, this research was undertaken to evaluate some properties of VLF juice, proximate chemical composition of VLF peels and produce some functional food products containing the juice, peels and the whole fruit (i.e. pickle, Jam, nectar, marmalade, cake, biscuits and crackers). Chemical composition showed that VLF peels contained $6.86 \%$ crude protein, $8.38 \%$ crude ether extract, $149.86 \mathrm{mg} / 100 \mathrm{~g}$ ascorbic acid, $16.06 \mathrm{mg} / 100 \mathrm{~g} \beta$-carotene and 1.89 $\mathrm{g} / 100 \mathrm{~g}$ total phenolics. Also, the results indicated that VLF peels are rich in minerals, dietary fiber and antioxidants. Limonene was the main component of VLF peel oil. Its concentration was $91.33 \%$. The most abundant monoterpene was pinene $(8.67 \%)$. The peel extract of VLF was effective in inhibiting all test bacteria expect Streptococcus dysgalactiae subsp. equisimilis (G-positive) and Pseudomonas aeruginosa ATCC 27853 (Gram-negative) which means that the peel extract is strong antimicrobial agent. The VLF juice, peels and fruits were used to formulate some important functional foods. The organoleptic properties of all processed products in the present study were well accepted among different panelists.
\end{abstract}

Keywords: Citrus volkameriana fruit, juice, peels, chemical composition, antioxidants, antimicrobial, organoleptic properties

\section{INTRODUCTION}

Volkamer lemon fruit (VLF) is of Italian origin and thought to be a natural hybrid of lemon and sour orange. This fruit is also known as volkamer lemon. The VLF has been known for centuries (lopes et al., 2011). Herbal extract may be a possible adjunctive method in management of chronic gingivitis (Mostafa \& Eid, 2017).

The spherical or oval fruits is medium (6- 6.5), weigh $130 \mathrm{~g}$ and resembles the lemon in shape. Its rind is yellow, later dark orange and then almost red, pebbled, rough and quite thin. The pulp is yellow or yellow -orange, very juicy, sour with a hint of bitterness, aromatic with excellent quality and usually divided into 7-11 segments with lots of small polyembryonic seeds. Fruiting trees are very decorative and the fruits can be used instead of lemons. It contains various types of antioxidants such as phenolic compounds, flavonoids, carotenoids and ascorbic acid. The carotenoids have been confirmed to have a vital function in preventing oxidative damage resulting from singlet oxygen and free radicals presence (Lina et al., 2003). The VLF is also an excellent rootstock and grows rapidly in a greenhouse. It can be used as a rootstock even after 1.5-2 years after germinating. Its compatibility with other citruses is excellent, more to that, it improves the resistance to gummosis, helps in proper development of grafted citrus and its high yields. It should mostly be used as a rootstock for lemons, other citruses, especially oranges which have less juice and more acids. Therefore, it is advised to use it as a rootstock in sandy soils and frost free climate for lemons, orange ' Valencia ' or ' Midsweet, but not for the cultivar ' Hamlin '. It is used as a rootstock in Brazil, Argentina and Florida.

Nasser et al. (2014) evaluated some new navel orange cultivars in Egypt budded on sour orange and volkamer lemon rootstocks. They found that the latter gave the significant highest values of flowering, fruit set, fruit drop, yield parameters , peel thickness, macro and micronutrients content ( $\mathrm{N}, \mathrm{P}, \mathrm{K}, \mathrm{Ca}, \mathrm{Mg}, \mathrm{Fe}, \mathrm{Zn}$ and $\mathrm{Mn}$ ) as compared with sour orange rootstock. 
So, no attention has been made to evaluate the physicochemical and technological properties of VLF fruit. Thus, the present research was undertaken to evaluate some properties of VLF juice, proximate chemical composition of VLF peels and the possibilities to produce some functional food products containing the juice, peels and the whole fruit.

\section{MATERIALS AND METHODS}

\section{Materials}

About $25 \mathrm{~kg}$ of VLF were obtained from a private farm, Idku, Behera Governorate, Egypt. All chemicals and reagents used in the present study were of analytical grade and purchased from ElGomhouria Co.,Alexandria, Egypt. Sweet and Washington navel orange, salt, vinegar, red peppers, carrot, sugar, wheat flour ( $72 \%$ extraction), vegetable oils, baking powder, egg, vanillin and liquid milk were purchased from the local market, Alexandria, Egypt.

\section{Methods}

\section{Physical methods}

Shape, skin, pulp colour, pulp and juicy center of VLF fruits were visually described. Number of fruits $/ \mathrm{kg}$, number of lobes, average fruit weight $(\mathrm{g} /$ fruit), average fruit volume $(\mathrm{cm} 3)$ and number of seeds / one fruit were determined as mentioned by Kramer \&Twigg (1973). Measurements of the three major perpendicular dimensions of the fruit, namely length, width and thickness were carried out with dernier calipers (Kanon Instruments, Japan) reading to $0.01 \mathrm{~mm}$.. In addition, juice, pulp, peel and the seeds of VLF were weighed by a top loading balance (model: D0001-HR120, AQD company, Limited EC).

The $\mathrm{pH}$ value was measured using glass electrode $\mathrm{pH}$ meter (Persicamodel $\mathrm{pH}$ 900, Switzerland) as described in the AOAC (2005). The total soluble solids (TSS) were determined using a digital refractometer (Hanna, HI 96811, Germany) as described in the AOAC (2005).

\section{Chemical methods}

\section{Proximate chemical composition}

Moisture, crude protein, crude ether extract and total ash of VLF peels were determined according to the AOAC (2005). Carbohydrate content was calculated by difference. Crude fiber, neu- tral detergent fiber (NDF) and acid detergent fiber (ADF) content were determined according to the AOAC method (2005) via filter bags technology (Fiber analyses, Ankon 200), USA model A220 . Minerals $(\mathrm{Ca}, \mathrm{Mg}, \mathrm{Mn}, \mathrm{Fe}$, and $\mathrm{Cu})$ were determined in the ash solution using Atomic Absorption Spectrophotometer (AAS) 600 VA- So- 60- H2100- $240 \mathrm{~V}$, UK. On the other hand, Na and K were determined using flame photometer model PEP7 as described in AOAC (2005).

\section{Total phenolic content}

Twenty five g powder of the peels were individually extracted with $250 \mathrm{ml}$ of $80 \%$ ethanol $(1: 10 \mathrm{w} / \mathrm{v})$ and the extraction was carried out twice, and the combined extracts were collected. The solvent was removed using rotary evaporator (IKA. Com BIMA RCD) at $50^{\circ} \mathrm{C}$. The extracts were lyophilized by using Vir Tis Scientific lyophilizer . The lyophilized extracts were kept in tightly closed brown bottles and stored at $-18^{\circ} \mathrm{C}$ until used. Yield was calculated as a percentage ( $\mathrm{g}$ extract/100 $\mathrm{g}$ sample). Total phenolics were determined using Folin-Ciocalteu reagent (Singleton et al., 1974).

\section{Antioxidant activity}

\section{The DPPH・ method}

Radical scavenging activity of peel extract was measured using the stable radical DPPH (2,2-diphenyl-1 - picrylhydrazyl) according to Brand Williams et al. (1995). The percentage of DPPH• scavenging for peel extract along with ascorbic acid as a standard was calculated as follows:

Scavenging \% $\left[(\mathrm{DPPH} \bullet]=\left[\left(\mathrm{Abs}_{\text {control }}-\mathrm{Abs}_{\text {sample }}\right)\right.\right.$ $\times 100$ ] / $\mathrm{Abs}_{\text {control }}$

The $\mathrm{IC}_{50}$ was determined using different concentrations of peel extract and ascorbic acid as standared control.

\section{Hydrogen peroxide method}

The ability of peel extract under study to scavenge hydrogen peroxide was determined according to Ruch et al. (1989). The percentage of $\mathrm{H}_{2} \mathrm{O}_{2}$ scavenging of peel extracts and ascorbic acid were calculated as follows:

Scavenging \% $\left[(\mathrm{H} 2 \mathrm{O} 2]=\left[\left(\mathrm{Abs}_{\text {control }}-\mathrm{Abs}_{\text {sample }}\right)\right.\right.$ $\times 100$ ] / $\mathrm{Abs}_{\text {control }}$

\section{Ascorbic acid content}

Ascorbic acid was determined using 2,6 dichlorophenol indophenol dye ( Ranganna, 1977), except that $4 \%$ oxalic acid in $8 \%$ glacial acetic acid was used for sample extraction ( Plummer, 1978). 


\section{$\beta$ - Carotene content}

The $\beta$ - Carotene content was extracted according to the method described by Tee et al. (1996). The $\beta$ - carotene was determined by RP-HPLC. A Hewlett packared HPLC series 1100, USA equipped with degasser, quaternary pump, auto sampler and diode array detector was used. The mobile phase was: acetone-methanol-ethyl acetate $(88: 10: 2 \mathrm{v} / \mathrm{v} / \mathrm{v})$ and the flow rate of $1.0 \mathrm{ml} / \mathrm{min}$.

\section{Isolation of essential oils}

One hundred g of dried and ground VLF peels were separated and hydro-distilled for $4 \mathrm{hr}$ using a Clevenger- type apparatus. The distilled essential oils were dried over anhydrous sodium sulphate and stored in sealed vials at $4{ }^{\circ} \mathrm{C}$ prior to further analysis (Kamal et al., 2011).

\section{Analysis of essential oils}

Gas chromatography /mass spectrometry (GC/ MS) analysis of the essential oils was performed using thermo Fisher Scientific Trace G ultra ISQ. Column: TG - 5SIL Ms length 30m, I.D.o.32 mm, Film: 0.25 um. Ms Transfer line temperature: $200^{\circ} \mathrm{C}$ and Ion source temperature: $200^{\circ} \mathrm{C}$ (Kamal et al., 2011).

\section{Antimicrobial assay Sample preparation and extraction}

The sample extraction was performed according to the method proposed by Darwish et al. (2018). The powdered sample was placed in a beaker and warm water was added at a ratio of $(1: 20 \mathrm{w} / \mathrm{v})$, stirred with a magnetic stirrer for $3 \mathrm{hr}$ at $60^{\circ} \mathrm{C}$, centrifuged using high speed centrifuge (Procentrifuge, Centurion Science Limited, UK) for 20 min at $3382 \mathrm{xg}$, and then lyophilized via vacuum freeze-dryer (Model FDF 0350, Korea).

\section{Microorganisms and culture conditions}

Ten pathogenic strains were used to scan sample's antimicrobial potentials; five Gram-positive strains; Staphylococcus aureus EMCC1351, Staphylococcus dysgalactiae subsp. Equisimilis, Streptocococcus mutans EMCC1815, Bacillus subtilis DB100 and Clostridium botulinum ATCC3584 and five Gram-negative strains; Proteus hauseri EMCC1227, Escherichia coli ATCC 25922, Escherichia coli BA12296, Klebsiella pneeumoniae EMCC1637 and pseudomonas aeruginosa ATCC 27853. All strains were obtained from Microbiological Resource Centre (MIRCEN), Faculty of Agriculture, Ain Shams University. Cairo, Egypt.

\section{Antimicrobial activity}

To examine antimicrobial activity of sample's extracts, well diffusion assay was used (Das et al., 2010), against ten phathogenic bacterial strains. The bacterial strains were grown in nutrient broth at $37^{\circ} \mathrm{C}$ for $24 \mathrm{hr}$. Briefly, $100 \mu \mathrm{L}$ of overnight activated culture of each pathogen strain (10 CFU/ $\mathrm{mL}$ ) were aseptically spread over nutrient agar plates. About $100 \mu \mathrm{L}$ of $100 \%$ extract was transferred into each agar well individually. The plates were incubated at $37^{\circ} \mathrm{C}$ for $18 \mathrm{hr}$ and the formed clear zones (if found) were measured and recorded. A set of 3 concentrations of sample extracts $(50,25$ and $12.5 \mathrm{mg} / \mathrm{ml}$ ), were examined to determine the minimum inhibitory concentration (MIC) of each against a specific pathogenic strain (Kadaikunnan et al., 2015). The zones of inhibition were calculated by measuring the diameter of the inhibition zone around the well $(\mathrm{mm})$, including the well diameter, the reading was taken in three different fixed directions in all duplicates and the average values were tabulated.

\section{Technological methods}

\section{Preparation of VLF}

The VLF were washed using tap water then drained. The fruits were divided into two parts:-

The first part: whole fruits were used for preparing VLF pickle and the second part: fruits were cut into two halves by stainless steel knife and then the juice was extracted using orange Juicer (Kenwood major titanium, Japan) and the juice was used for preparing organic juice and jam which was used for preparing Swiss-roll. Fresh peels were used for preparing marmalade and the other part of fresh peels were air dried $(18 \mathrm{hr}-40 \mathrm{oC})$ then ground (Moulinex- AR1044), sieved through 80 mesh sieve and used to prepare cake, biscuits and crackers. Fig (1) shows the flow sheet for preparing the aforementioned products.

\section{Preparation of VLF products}

\section{Pickle}

The VLF pickle was prepared from whole VLF fruits using water, $10 \%$ salt, vinegar $5 \%$ and moderately amount of hot red peppers. It was mixed well and stored in airtight containers at room temperature for a period of 3 to 4 weeks, then the VLF pickle was subjected to sensory evaluation (Divya et al., 2016) 


\section{Jam}

The VLF jam was made from the juice (pulp) which was replaced with $0,25,50$, and $75 \%$ minced carrot using sugar to juice ratio of $1: 1(\mathrm{w} / \mathrm{w})$ with $0.4 \%$ citric acid and $0.7 \%$ pectin. The prepared jam was packed in sterilized glass jars and stored at room temperature until used for sensory evaluation (Minifie, 1982).

\section{Nectar}

The VLF nectar products were prepared by mixing VLF juice (25\%) with water $(75 \%)$.Sugar was added until the TSS reached 150 Brix. The VLF juice was replaced with 25, 50, 75\% Washington navel and sweet orange. The prepared VLF nectar was hot filling into pasteurized glass bottle and then sealed and stored at room temperature until sensory evaluated.

\section{Marmalade}

Marmalade was made from $350 \mathrm{~g}$ fresh peels of VLF using, $650 \mathrm{~g}$ sugar, $5 \mathrm{~g}$ pectin and $5 \mathrm{~g}$ citric acid. The prepared marmalade was packed in sterilized glass jars.

\section{Swiss-rolls}

The VLF jam was used to prepare swiss-rolls product as mentioned by Fance (1969) .

\section{Cake}

The Cake product was prepared from blends containing $0,5,10,15$ and $20 \%$ of VLF peel powder according to Sing et al.(2006).

\section{Biscuits and crackers}

Biscuits and crackers were processed according to the method described by Askar (1991) and Ahmed \&Abozed (2015), respectively. The effect of adding VLF peel powder at levels of 2.5, 5, 7.5, and $10 \%$ levels based on the weight of wheat flour was studied. Swiss-rolls, cake, Biscuits and crackers formulas are shown in Table (1).

\section{Statistical analysis}

All data were expressed as mean values \pm SD. The data of the organoleptic properties of VLF products were subjected to analysis of variance using (ANOVA) followed by Duncan's multiple range test with $\mathrm{P} \leq 0.05$ being considered statisti-

Table1: Ingredients used for the preparation of Swiss-rolls, cake,biscuits and crackers.

\begin{tabular}{|l|c|c|c|c|}
\hline Ingredients $(\mathrm{g})$ & Swiss-rolls & Cake & Biscuits & Crackers \\
\hline Wheat flour & 120 & 120 & 250 & 375 \\
\hline Baking powder & 5 & 0.5 & 4.0 & 2 \\
\hline Ammonium bicarbonate & - & - & 1.25 & - \\
\hline Whole egg (number) & 4 & 2 & 1 & - \\
\hline Sugar & 120 & 100 & 100 & - \\
\hline Liquid milk (ml) & - & - & 25 & - \\
\hline Shortening & - & 25 & 100 & 20 \\
\hline Sodium bicarbonate & - & - & 0.50 & - \\
\hline Vanillin & 5 & 1 & 1.25 & - \\
\hline VLF jam & 100 & - & - & - \\
\hline Sodium chloride & - & 2.3 & 1.0 & 2 \\
\hline Milk powder & - & 14 & - & 125 \\
\hline Dried active baker's yeast & - & - & - & 2 \\
\hline
\end{tabular}

Volkamer lemon fruit (VLF)

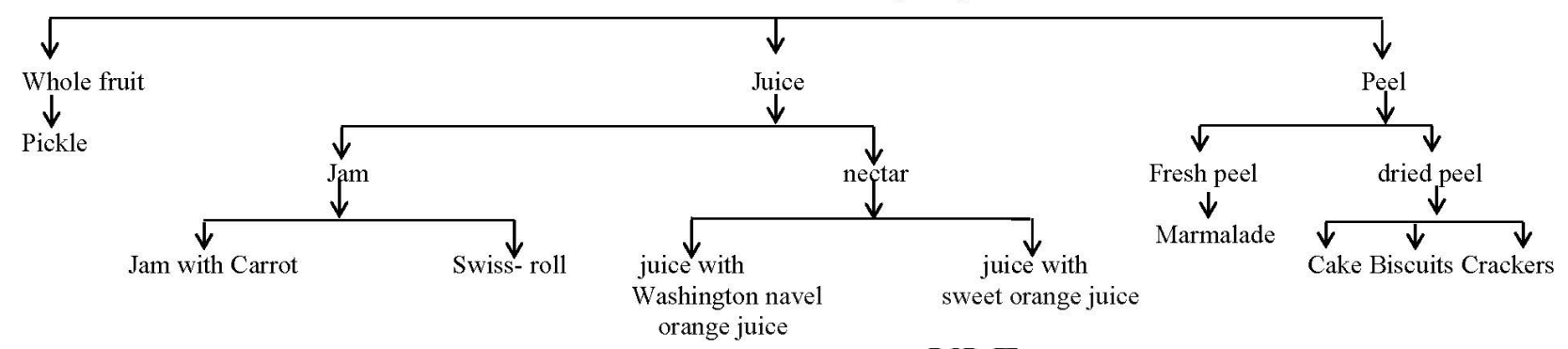

Fig. 1: Flow sheet for preparing some VLF fruit products 
cally significant using SAS program software program (SAS Institute 2004).

\section{RESULTS AND DISCUSSION}

\section{Fruit properties:}

Fig.(2) shows the appearance and general properties of VLF . Also, Fruit dimensions, weight compositions and properties of juice are given in Table (2).
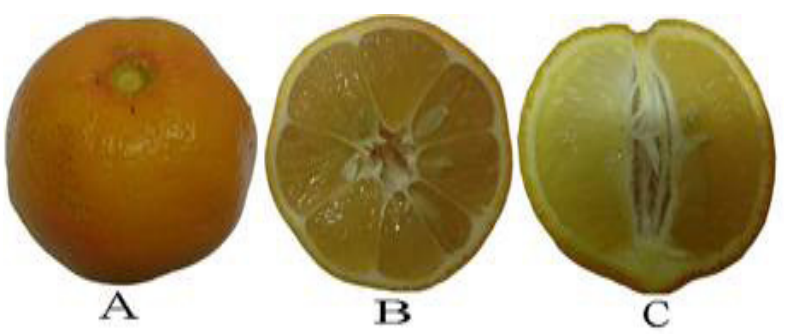

Fig. 2: General appearance of: whole VLF (A), Cross section of half of VLF (B), a long section of half of VLF (C)

Table 2: General properties of Citrus volkameriana fruit (VLF)

\begin{tabular}{ll}
\hline Parameter & Description \\
\hline Appearance properties & Round \\
Shape & $\begin{array}{l}\text { Deep orange } \\
\text { Skin colour }\end{array}$ \\
pulp colour & $\begin{array}{l}\text { Juicy and acidic } \\
\text { highly acidic }\end{array}$ \\
pulp & Value * \\
Juice & $9.00 \pm 0.18$ \\
General properties & $8.30 \pm 1.25$ \\
Number of fruits/ $\mathrm{kg}$ & $115.90 \pm 6.33$ \\
Number of lobes/ fruit & $112.54 \pm 4.80$ \\
Average fruit weight (g/fruit) & $22.00 \pm 6.32$ \\
Average fruit volume (cm3/fruit & \\
Number of seeds/one fruit & \\
Fruit dimensions (cm) & $6.05 \pm 2.95$ \\
Length & $5.88 \pm 1.19$ \\
Width & $5.88 \pm 1.17$ \\
Thickness & \\
Weight composition (\%) & $44.34 \pm 2.10$ \\
Juice & $27.29 \pm 1.31$ \\
Pulp (white fiber) & $25.45 \pm 1.73$ \\
Peel & $2.92 \pm 0.70$ \\
Seeds & \\
Properties of juice & $8.30 \pm 0.577$ \\
Total soluble solids(\%) & $1.38 \pm 0.09$ \\
pH value & $6.60 \pm 0.81$ \\
Titratable acidity (\%) & \\
\hline
\end{tabular}

*means value of 3 replicates \pm S.D
Proximate chemical composition, total phenolic, ascorbic acid, $\beta$ - carotene and antioxidant activity of VLF peel:

The proximate chemical composition of VLF peel are given in Table (3). The moisture content was $82.50 \%$. It has been reported that the moisture content of citrus peels varied between 74.8 and $76.01 \%$ (Kammoun et al., 2011, M'hiri et al., 2015).Meanwhile, Zoair et al. (2017) found that the moisture content of orange peel was $71.98 \%$ which showed a significant difference from the moisture content of VLF peel.

Crude protein content of VLF peel was $6.86 \%$ which was quite close to the crude protein of orange peel reported by Zoair et al. (2017). On the other hand, M'hiri et al. (2015) indicated that crude protein content of orange peel was much higher than that found in VLF being $8.12 \%$. Janati et al. (2012) found that protein content of lemon peel was $9.42 \%$. Also, Olabinjo et al. (2017) found that sweet orange rinds (peels) contained $45-50 \%$ of the total mass. They showed that sweet orange peels contained $7.15 \%$ protein and $12.79 \%$ crude fiber. These peels can be used as ingredients in processed food. These uses will promote sustainable disposal of orange peels.

As it can be noted from Table (3), the crude ether extract of VLF was $8.376 \%$. It has been reported that the total lipids of orange peel were $13.12 \%$ which was higher than that reported in the present study (Al-saadi et al.,2009). On the other hand, Zoair et al. (2017) found that orange peel had $10.17 \%$ total lipids. Table (3) also shows that the total ash of CV peel was $6.78 \%$ while the total carbohydrate content was $77.99 \%$. These results agreed with those found for orange peels by Zoair et al. (2017). The results indicated that carbohydrate was the most abundant component for VLF peels.

Total phenolics and ascorbic acid contents are presented in Table (3). Their values were $1.83 \mathrm{~g}$ gallic acid equivalent $/ 100 \mathrm{~g}$ and $149.9 \mathrm{mg} / 100 \mathrm{~g}$, respectively. It is well known that total phenolics and ascorbic acid act as potential antioxidants and may possess synergetic effect. These results confirm the significance of utilizing VLF as potential natural antioxidant. It has been reported that the antioxidant capacities of four citrus species were correlated to ascorbic acid and phenolic acid( Barros et al., 2012). These bioactive components can be 
Table 3: Proximate chemical composition, total phenolic, bic acid as a reference antioxidant was ascorbic acid, $\beta$-carotene contents, and antioxi- $22.07 \mathrm{mg}$ extract/ mg DPPH. The $\mathrm{H}_{2} \mathrm{O}_{2}$ dant activity of VLF peels

\begin{tabular}{ll}
\hline Component & Value (\%) \\
\hline Moisture content & $82.5004 \pm 0.72$ \\
Crude protein & $6.857 \pm 0.21$ \\
Crude ether extract & $8.376 \pm 0.34$ \\
Total ash & $6.778 \pm 0.13$ \\
Carbohydrate* & 77.989 \\
Total phenolics & $1825.63 \mathrm{mg} / 100 \mathrm{~g} * * \pm 2.63$ \\
Ascorbic acid & $149.86 \mathrm{mg} / 100 \mathrm{~g} \pm 0.28$ \\
$\beta-$ Carotene & $16.06 \mathrm{mg} / 100 \mathrm{~g} \pm 0.13$ \\
DPPH\% scavenging & $75.63 \pm 1.55$ \\
IC50 & $8.16 \mathrm{mg} / \mathrm{mg} \mathrm{DPPH} \pm 0.12$ \\
DPPH \% scavenging of ascorbic acid & $95.25 \pm 1.73$ \\
IC50 mg/mg DPPH of ascorbic acid & $22.07 \pm 0.26$ \\
H2O2 \% scavenging & $63.35 \pm 2.34$ \\
H2O2\% scavenging of ascorbic acid & $97.73 \pm 2.03$ \\
\hline
\end{tabular}
scavenging activity was $63.35 \%$ for VLF peels while for the ascorbic was $97.73 \%$. The data obtained in the present study agreed with those reported by Abd El-aal \&Halaweish (2010)and Zoair et al.(2017). They reported that the DPPH scavenging activity of three cultivars of citrus peels varied from 55 to $72 \%$. The potent antioxidant activity of such peels can be attributed to their high content of phenolics (Oroian and Escriche, 2015).

\section{Fiber composition and mineral con- tents of VLF}

The crude fiber content of VLF as well as neutral detergent fiber (NDF), acid detergent fiber (ADF) and hemicellulose contents are given in Table (4). The VLF had 10.47 crude fiber, 35\% (NDF), $28.80 \%$ (ADF) and 6.20 hemicellulose. In Results are expressed as mean of three replicates \pm SD.

* By difference

** Gallic acid equivalent / $100 \mathrm{~g}$

explored for their health promoting values in food products. Divya et al. (2016) found that the total phenolics of pulp and peel fragments of bitter orange (naring) ranged from 2.5 to $22.5 \mathrm{mg} / \mathrm{g}$ and 5 to $45.0 \mathrm{mg} / \mathrm{g}$, respectively. They concluded that bitter orange exhibited high antioxidant capacity which was retained even in processed and stored products. On the other hand, Ibrahim \&Hamed (2018) found that naringin and hesperidin were the predominant phenolic acids in lemon and orange peels. Further, Rafiq et al. (2018) concluded that citrus peel can be considered as a good source of functional ingredients such as phenolic compounds, flavonoids and dietary fibers. These constituents are beneficial nutrients for human beings.

$\beta$ - Carotene content for VLF peels was slightly low being $16.06 \mathrm{mg} / 100 \mathrm{~g}$. In accordance with the results obtained in the present study, Zoair et al. (2017) found that orange peels had only 6.15 $\mathrm{mg} / 100 \mathrm{~g} \beta$ - carotene.

The data given in Table (3) show that VLF peels had $75.63 \%$ DPPH scavenging activity while ascorbic acid exhibited DPPH scavenging activity of $95.25 \%$. The $\mathrm{IC}_{50}$ is defined as the concentration of sample that scavenges $50 \%$ of DPPH. VLF peels had $8.16 \mathrm{mg}$ extract/mg DPPH while $\mathrm{IC}_{50}$ of ascoraccordance with the results obtained in the present study, Zoair et al. (2016) found that the aforementioned values were 12.0, $19.13,12.6$ and $6.53 \%$, respectively. Also, Janati et al. (2012) found that the level of crude fiber in lemon peels was $15.18 \%$. While Olabinjo et al. (2017) found that sweet orange peels contained $12.79 \%$ crude fiber.

Table 4: Fiber composition and mineral contents of VLF on dry weight basis

\begin{tabular}{ll}
\hline Component & Value \\
\hline Fiber & $\mathbf{( \% )}$ \\
Crude fiber & 10.47 \\
$\mathrm{NDF}$ & 35.00 \\
$\mathrm{ADF}$ & 28.80 \\
Hemicellulose* & 6.20 \\
Minerals & $\mathbf{m g / 1 0 0 g}$ \\
$\mathrm{Na}$ & 48.81 \\
$\mathrm{~K}$ & 66.66 \\
$\mathrm{Ca}$ & 196.10 \\
$\mathrm{Mg}$ & 18.08 \\
$\mathrm{Fe}$ & 1.26 \\
$\mathrm{Mn}$ & 2.36 \\
$\mathrm{Cu}$ & 0.45 \\
\hline
\end{tabular}

$\mathrm{NDF}=$ neutral detergent fiber (NDF) and

$\mathrm{ADF}=$ acid detergent fiber

*calculated by difference (NDF-ADF) 
Mineral contents of VLF are given in Table (4). It can be noted that $\mathrm{Ca}, \mathrm{K}$ and $\mathrm{Na}$ possessed the higher values comparing with the other studied elements.Rachel et al. (2013) found that $\mathrm{K}$ and $\mathrm{Ca}$ were the major elements of orange peels. Barros et al. (2012) showed that Ca content of two different varieties of orange peels varied from 145.9 to 165.4 $\mathrm{mg} / 100 \mathrm{~g}$ which are smaller than the values of $\mathrm{Ca}$ in the VLF. On the other hand, Zoair et al. (2016) found that orange peel had 42.81, 46.66, 176.10, $8.08,3.37,1.16$ and $0.66 \mathrm{mg} / 100 \mathrm{~g}$ of $\mathrm{Na}, \mathrm{K}, \mathrm{Ca}$, $\mathrm{Mg}, \mathrm{Fe}, \mathrm{Mn}$ and $\mathrm{Cu}$, respectively. Further, Janati et al. (2012) found higher values for the levels of minerals in lemon peels comparing with the results of the present study.

\section{Chemical compounds of the essential oils in} the fresh VLF peel

It has been found that the extract yield of essential oils was $0.70 \%$. Limonene was the main component of VLF peel oil its weight concentration was $91.33 \%$. After limonene, the most abundant monoterpene was pinene (8.67\%). Combariza et al. (1994) found that the limonene concentration in VLF peel oil reached a maximum level of $79.4 \%$ when the fruit was in the intermediate maturation stage characterized by greenish- yellow coloration. Kamal et al. (2011) studied the yield and chemical composition of citrus essential oils as affected by drying pretreatment of peels. They Table 5: found that the most prevalent chemical constituent was limonene which varied significantly with respect to drying treatments and species used. Also, it has been reported that bitter orange peel contains a volatile oil with limonene (about 90\%), flavonoids, coumarins, tri-terpenes, vitamin C , carotene and pectin (Suryawanshi, 2011). On the other hand, Deterre et al. (2014) found that limonene, myrcene and $\alpha$-pinene were the dominant volatile compounds of the bitter orange essential oils. Furthermore, Suntar et al. (2018) showed that bitter orange contained limonene, linalool and $\beta$-myrcene. They concluded that both the extract and isolated compounds have no unwanted effect in human as therapeutic and therefore can confidently be used in various dietary formulations.

\section{Antimicrobial activity}

The result of antibacterial activity of
VLF peel extract is shown in Table (5). The peel extract of VLF was effective in inhibiting all test bacteria expect Streptococcus dysgalactiae subsp. equisimilis (G-positive) and Pseudomonas aeruginosa ATCC 27853 (Gram-negative).. The antimicrobial efficacy of peel extract can be ascribed to the presence of secondary metabolites. Madhuri et al. (2014) reported that the peel extracts of two citrus species exhibited inhibitory effect against bacteria and C. capsici. They mentioned that the peel extracts of selected citrus fruits can be used against infectious agents.

\section{Sensory evaluation}

Table (6) shows the sensory evaluation of the different products including marmalade, jam, Swiss roll and pickle prepared from VLF. The data indicated that all these products were extremely accepted by the panelists except the jam which was less acceptable. All the values for colour, taste, odour, texture and overall acceptability varied between 7.3 to 8.6. These results indicated that VLF can be used as a good citrus fruit to prepare such products which are acceptable by the different categories of people.

The results obtained in Table (7) indicated that jam containing 25 and $50 \%$ carrot was more or less the same from the sensory point of view.

\section{Antimicrobial activity of VLF peel extract against} different pathogenic strains

\begin{tabular}{llll} 
& \multicolumn{3}{c}{$\begin{array}{c}\text { Inhibition Zone } \\
\text { Piameter (mm)** }\end{array}$} \\
\cline { 2 - 5 } Gathogenic strain & $\mathbf{5 0 *}$ & $\mathbf{2 5}$ & $\mathbf{1 2 . 5}$ \\
Staphylococcus aureusEMCC1351 & & & \\
Streptococcus dysgalactiae subsp. equisimilis & ND & ND & ND \\
Streptococcus mutansEMCC1815 & 18 & 12 & 10 \\
Bacillus subtilis DB 100 & 10 & 7 & ND \\
Clostridium botulinum ATCC 3584 & 19 & 15 & 13 \\
Gram-negative bacteria & & & \\
Proteus hauseriEMCC1227 & 28 & 23 & 12 \\
Escherichia coli ATCC 25922 & 8 & ND & ND \\
Escherichia coli BA 12296 & 35 & 22 & 8 \\
Kelebsellia pneumonia ATCC 12296 & 23 & 19 & 13 \\
Pseudomonas aeruginosa ATCC 27853 & ND & ND & ND \\
\hline
\end{tabular}

MIC; Minimum Inhibition Concentration

${ }^{*}$ Concentrations of extract and MIC are in $(\mathrm{mg} / \mathrm{mL})$

** Diameter included $\mathrm{mm}$ well diameter

ND; Not detected 
Table 6: Sensory evaluation of processed VLF products

\begin{tabular}{lccccc}
\hline \multicolumn{1}{c}{ Treatments } & Colour & Taste & Odour & Texture & $\begin{array}{c}\text { Overall } \\
\text { Acceptability }\end{array}$ \\
\hline Marmalade & $8.4 \pm 0.52^{\mathrm{a}}$ & $7.7 \pm 0.48^{\mathrm{b}}$ & $8.2 \pm 0.63^{\mathrm{a}}$ & $8.0 \pm 0.82^{\mathrm{a}}$ & $8.3 \pm 0.67^{\mathrm{a}}$ \\
Jam & $8.1 \pm 0.57^{\mathrm{a}}$ & $7.3 \pm 1.16^{\mathrm{b}}$ & $7.6 \pm 0.52^{\mathrm{b}}$ & $7.3 \pm 1.06^{\mathrm{b}}$ & $7.6 \pm 0.70^{\mathrm{b}}$ \\
Swiss-roll & $8.5 \pm 0.52^{\mathrm{a}}$ & $8.1 \pm 0.99^{\mathrm{a}}$ & $8.3 \pm 0.95^{\mathrm{a}}$ & $8.5 \pm 0.97 \mathrm{a}$ & $8.3 \pm 0.92^{\mathrm{a}}$ \\
pickle & $8.5 \pm 0.53^{\mathrm{a}}$ & $8.35 \pm 0.47^{\mathrm{a}}$ & $8.4 \pm 0.52^{\mathrm{a}}$ & $8.35 \pm 0.47^{\mathrm{a}}$ & $8.6 \pm 0.46^{\mathrm{a}}$ \\
\hline
\end{tabular}

Means in a column not sharing the same letter are significantly different at $\mathrm{P} \leq 0.05$.

Table 7: Sensory evaluation of different products from VLF and other materials

\begin{tabular}{|c|c|c|c|c|c|c|}
\hline Products & Treatments & Colour & Taste & Odour & Texture & $\begin{array}{c}\text { Overall } \\
\text { acceptability }\end{array}$ \\
\hline \multirow{5}{*}{$\begin{array}{l}\text { Jam } \\
\text { (VLF juice and carrot) }\end{array}$} & $\mathrm{T} 1$ & $8.9 \pm 0.32^{\mathrm{a}}$ & $8.0 \pm 0.47^{\mathrm{a}}$ & $8.4 \pm 0.70^{\mathrm{a}}$ & $8.6 \pm 0.52^{a}$ & $8.4 \pm 0.52^{\mathrm{a}}$ \\
\hline & $\mathrm{T} 2$ & $8.3 \pm 0.67 \mathrm{ab}$ & $8.1 \pm 0.99^{a}$ & $8.0 \pm 0.94 \mathrm{a}$ & $8.2 \pm 0.78^{\mathrm{ab}}$ & $8.15 \pm 0.58^{\mathrm{a}}$ \\
\hline & $\mathrm{T} 3$ & $8.2 \pm 1.03^{\mathrm{ab}}$ & $7.5 \pm 1.08^{\mathrm{a}}$ & $7.8 \pm 0.78^{\mathrm{a}}$ & $7.6 \pm 1.07^{\mathrm{b}}$ & $7.9 \pm 0.74^{\mathrm{a}}$ \\
\hline & $\mathrm{T} 4$ & $8.1 \pm 0.88^{\mathrm{b}}$ & $7.5 \pm 1.18^{\mathrm{a}}$ & $7.7 \pm 1.34^{\mathrm{a}}$ & $8.0 \pm 1.15^{\mathrm{ab}}$ & $7.89 \pm 1.27 \mathrm{a}$ \\
\hline & LSD & 0.70 & 0.88 & 0.88 & 0.83 & 0.77 \\
\hline \multirow{5}{*}{$\begin{array}{l}\text { Nectarine } \\
\text { (VLF juice and Washington } \\
\text { navel orange juice) }\end{array}$} & $\mathrm{T} 1$ & $8.30 \pm 0.67$ a & $7.85 \pm 0.75^{\mathrm{a}}$ & $8.00 \pm 0.47$ a & $8.15 \pm 0.74$ a & $7.85 \pm 0.67$ a \\
\hline & $\mathrm{T} 2$ & $7.90 \pm 0.74 \mathrm{ab}$ & $8.05 \pm 0.49$ a & $7.8 \pm 0.79$ a & $7.9 \pm 0.87$ a & $7.95 \pm 1.01 \mathrm{a}$ \\
\hline & $\mathrm{T} 3$ & $7.38 \pm 0.99$ b & $7.33 \pm 0.71^{\mathrm{a}}$ & $7.61 \pm 0.69 \mathrm{a}$ & $7.77 \pm 0.83 \mathrm{a}$ & $7.44 \pm 0.73$ a \\
\hline & $\mathrm{T} 4$ & $7.5 \pm 1.18 \mathrm{ab}$ & $7.25 \pm 1.36 \mathrm{a}$ & $7.50 \pm 0.97$ a & $7.50 \pm 1.18 \mathrm{a}$ & $7.10 \pm 1.28$ a \\
\hline & LSD & 0.824 & 0.80 & 0.704 & 0.846 & 0.888 \\
\hline \multirow{5}{*}{$\begin{array}{l}\text { Nectarine } \\
\text { (VLF juice and sweet orange } \\
\text { juice) }\end{array}$} & $\mathrm{T} 1$ & $8.05 \pm 0.83^{\mathrm{a}}$ & $8.15 \pm 0.67^{\mathrm{a}}$ & $7.9 \pm 0.74^{\mathrm{ab}}$ & $8.45 \pm 0.70^{\mathrm{a}}$ & $8.30 \pm 0.48^{a}$ \\
\hline & $\mathrm{T} 2$ & $8.40 \pm 0.97^{\mathrm{a}}$ & $8.1 \pm 0.74^{\mathrm{a}}$ & $8.30 \pm 1.06^{\mathrm{ab}}$ & $8.48 \pm 0.85^{\mathrm{a}}$ & $8.45 \pm 0.80^{\mathrm{a}}$ \\
\hline & $\mathrm{T} 3$ & $8.60 \pm 0.69^{a}$ & $8.1 \pm 0.88^{\mathrm{a}}$ & $8.50 \pm 0.85^{\mathrm{a}}$ & $8.55 \pm 0.85^{\mathrm{a}}$ & $8.60 \pm 0.57^{\mathrm{a}}$ \\
\hline & $\mathrm{T} 4$ & $7.1 \pm 0.99^{b}$ & $7.1 \pm 0.88^{b}$ & $7.65 \pm 0.88^{b}$ & $7.93 \pm 0.95^{\mathrm{a}}$ & $7.55 \pm 0.64^{b}$ \\
\hline & LSD & 0.799 & 0.721 & 0.807 & 0.763 & 0.574 \\
\hline
\end{tabular}

Means in a column not sharing the same letter are significantly different at $\mathrm{P} \leq 0.05$.

T1: $25 \%$ VLF juice $+75 \%$ other materials

T2: $50 \%$ VLF juice $+50 \%$ other materials

T3: $75 \%$ VLF juice $+25 \%$ other materials

T4: $100 \%$ VLF juice

They were well acceptable by the panelists. When the $\%$ of carrot increased, the acceptability of the resultant jam increased. So, it is recommended to add $50 \%$ carrot when jam is prepared from VLF. The addition of carrot can break or hinder the bitter taste of this fruit

The data in Table (7) show that Washington navel orange juice as well as sweet orange juice was used to dilute the acidity of VLF juice. The aforementioned two juices were added to VLF juice at levels of 25,50 and $75 \%$. It can be noted that by increasing percentage of Washington navel orange juice to VLF juice, the acceptability declined but still acceptable by the panelists. The VLF juice containing $75 \%$ orange juice as well as

VLF juice also was lower acceptable comparing with the other juices containing 25 and $50 \%$. Even though these juices are still like moderately by the panelists. On the other hand, it can be concluded that by increasing the percentage of sweet orange juice from $25 \%$ to $75 \%$, the sensory attributes of the resultant nectarine increased and well accepted by the panelists. Although nectarine containing 75\% sweet orange juice slightly decreased from the sensory point of view. The results indicated that this is another way to produce nectarine which is an acceptable or preferable product by the consumers.

The sensory attributes of cake, biscuits and crackers supplemented with different levels of VLF peels are presented in Table (8). It can be noted that 
Table 8: Sensory evaluation of cake, biscuits and crackers supplemented with different levels of VLF peels

\begin{tabular}{cllllll}
\hline Products & Treatments & Colour & \multicolumn{1}{c}{ Taste } & \multicolumn{1}{c}{ Odour } & \multicolumn{1}{c}{ Texture } & $\begin{array}{c}\text { Overall } \\
\text { Acceptability }\end{array}$ \\
\hline \multirow{6}{*}{ Cake } & Control & $8.66 \pm 0.82^{\mathrm{a}}$ & $8.6 \pm 0.74^{\mathrm{a}}$ & $8.4 \pm 0.91^{\mathrm{a}}$ & $8.4 \pm 0.83^{\mathrm{a}}$ & $8.6 \pm 0.49^{\mathrm{a}}$ \\
& $5 \%$ & $8.10 \pm 0.80^{\mathrm{ab}}$ & $7.87 \pm 0.74^{\mathrm{ab}}$ & $7.73 \pm 0.80^{\mathrm{ab}}$ & $7.87 \pm 0.74^{\mathrm{ab}}$ & $8.00 \pm 0.65^{\mathrm{ab}}$ \\
& $10 \%$ & $7.87 \pm 0.74^{\mathrm{bc}}$ & $7.33 \pm 0.82^{\mathrm{bc}}$ & $7.40 \pm 0.82^{\mathrm{b}}$ & $7.93 \pm 0.88^{\mathrm{ab}}$ & $7.67 \pm 0.62^{\mathrm{bc}}$ \\
& $15 \%$ & $7.53 \pm 0.99^{\mathrm{bc}}$ & $6.87 \pm 0.83^{\mathrm{cd}}$ & $7.07 \pm 1.03^{\mathrm{bc}}$ & $7.27 \pm 1.10^{\mathrm{bc}}$ & $7.27 \pm 0.97^{\mathrm{cd}}$ \\
& $20 \%$ & $7.13 \pm 1.55^{\mathrm{c}}$ & $6.47 \pm 1.6^{\mathrm{d}}$ & $6.47 \pm 1.30^{\mathrm{c}}$ & $6.67 \pm 1.63^{\mathrm{c}}$ & $6.67 \pm 1.54^{\mathrm{d}}$ \\
& LSD & 0.75 & 0.75 & 0.72 & 0.97 & \\
\hline \multirow{5}{*}{ Biscuits } & Control & $8.13 \pm 0.74^{\mathrm{a}}$ & $8.27 \pm 0.80^{\mathrm{a}}$ & $7.53 \pm 1.25^{\mathrm{a}}$ & $7.7 \pm 1.07^{\mathrm{a}}$ & $8.23 \pm 0.90^{\mathrm{a}}$ \\
& $2.5 \%$ & $7.97 \pm 0.66^{\mathrm{a}}$ & $7.47 \pm 1.06^{\mathrm{ab}}$ & $7.20 \pm 0.77^{\mathrm{ab}}$ & $7.73 \pm 0.88^{\mathrm{a}}$ & $7.63 \pm 0.72^{\mathrm{ab}}$ \\
& $5 \%$ & $7.20 \pm 0.77^{\mathrm{b}}$ & $6.93 \pm 1.12^{\mathrm{bc}}$ & $6.57 \pm 1.24^{\mathrm{bc}}$ & $7.50 \pm 1.05^{\mathrm{a}}$ & $7.00 \pm 0.82^{\mathrm{bc}}$ \\
& $7.5 \%$ & $7.13 \pm 1.17^{\mathrm{b}}$ & $6.53 \pm 1.30^{\mathrm{cd}}$ & $6.40 \pm 1.49^{\mathrm{bc}}$ & $7.30 \pm 1.27^{\mathrm{a}}$ & $6.87 \pm 1.17^{\mathrm{c}}$ \\
& $10 \%$ & $6.70 \pm 1.27^{\mathrm{b}}$ & $5.90 \pm 1.31^{\mathrm{d}}$ & $6.13 \pm 1.36^{\mathrm{c}}$ & $7.03 \pm 1.29^{\mathrm{a}}$ & $6.00 \pm 1.19^{\mathrm{d}}$ \\
& LSD & 0.70 & 0.83 & 0.91 & 0.82 & 0.72 \\
\hline \multirow{6}{*}{ Crackers } & Control & $7.86 \pm 0.77^{\mathrm{a}}$ & $7.89 \pm 1.06^{\mathrm{a}}$ & $7.40 \pm 1.04^{\mathrm{a}}$ & $7.5 \pm 0.94^{\mathrm{a}}$ & $8.00 \pm 0.68^{\mathrm{a}}$ \\
& $2.5 \%$ & $7.50 \pm 0.52^{\mathrm{ab}}$ & $7.04 \pm 1.18^{\mathrm{ab}}$ & $7.04 \pm 1.01^{\mathrm{a}}$ & $7.43 \pm 1.02^{\mathrm{a}}$ & $7.39 \pm 0.53^{\mathrm{ab}}$ \\
& $5 \%$ & $6.64 \pm 0.99^{\mathrm{bc}}$ & $6.21 \pm 0.89^{\mathrm{bc}}$ & $6.04 \pm 1.15^{\mathrm{b}}$ & $6.43 \pm 0.85^{\mathrm{b}}$ & $6.82 \pm 0.54^{\mathrm{b}}$ \\
& $7.5 \%$ & $6.29 \pm 1.20^{\mathrm{cd}}$ & $5.36 \pm 1.34^{\mathrm{c}}$ & $5.14 \pm 1.29^{\mathrm{bc}}$ & $5.36 \pm 1.39^{\mathrm{c}}$ & $5.75 \pm 1.01^{\mathrm{c}}$ \\
& $10 \%$ & $5.54 \pm 1.91^{\mathrm{d}}$ & $3.71 \pm 1.54^{\mathrm{d}}$ & $4.96 \pm 1.67^{\mathrm{c}}$ & $4.96 \pm 1.78^{\mathrm{c}}$ & $4.86 \pm 1.51^{\mathrm{d}}$ \\
& LSD & 0.88 & 0.92 & 0.95 & 0.94 & 0.70 \\
\hline
\end{tabular}

Means in a column not sharing the same letter are significantly different at $\mathrm{P} \leq 0.05$.

by increasing the supplemented level of VLF peel in the aforementioned three products, the sensory attributes decreased but the products were still acceptable by the panelists except in case of crackers with 7.5 and $10 \%$ supplemented VLF peels. These crackers were significantly declined regarding their acceptability. The results indicated that cake, biscuits and crackers supplemented with 15, 5 and 2.5 $\%$ VLF peel, respectively, can give good acceptability from the sensory point of view.

According to Zoair et al. (2016) sensory evaluation revealed significant improvement of cakes supplemented with different levels of orange peels up to $20 \%$ and improved the texture of the crackers.

In a conclusion it can be noted that whole fruit, Juice (bulb), fresh peels and dehydrated peels can be used to prepare some delicious food products.

\section{REFERENCES}

Abd El-aal, H. A. \& Halaweish, F. T. 2010. Food preservative activity of phenolic compounds in orange peel extracts (Citrus sinensis L). LucrăriŞtiinţifice, 53: 233-40.
Ahmed, Z.S. \& Abozed, S.S.2015. Functional and antioxidant properties of novel snack crackers incorporated with Hibiscus sabdariff by product. Journal of Advanced Research, 6: 79-87.

Al-Saadi, N. H. M., Ahmad, N. S. \& Sa'eed, S. E. 2009. Determination of some chemical compounds and the effect of oil extract from orange peel on some pathogens Journal of Kerbala University. 7: 33-39.

AOAC 2005. Official Method of Analysis. 17thed. Association of Official Analytical Chemists, Gaithersburg Maryl, U.S. A.

Askar, D. H. S. 1991. Chemical and Technological Studies on Safflower Seeds. M. Sc. Thesis, Alexandria University, Egypt.

Barros, H. R., Ferreira, T. A. \& Genovese, M.I. 2012. Antioxidant capacity and mineral content of pulp and peel from commercial cultivars of citrus from Brazil. Food Chemistry, 134: 1892-1898.

Brand-Williams, W., Cuvelier, M.E. \&Berst, C. 1995. Use of a free radical method to evaluate 
antioxidant activity . Lebensmittel- Wissenschaft und Technologie, 28:25-30.

Combariza, M.Y., Tirado, C.B.\&stashenko, E.1994. Limonene concentration in Lemon (citrus Volkameriana) peel oil as function of ripeness. Journal of High Resolution Chromatography, 17:643-646.

Darwish, A.M.G., Khalifa, R.E. \& El Sohaimy, S.A.2018. Functional properties of Chia seed mucilage supplemented in low fat yoghurt. Alexandria Science Exchange Journal, 39: 450- 459.

Das,K., Tiwari, R.K.S. \&Shrivastaava, D.K.2010. Techniques for evaluation of medicinal plant products as antimicrobial agents: current methods and future trends. Journal of Medicinal Plants Research, 4: 104-111.

Deterre, S.C.,Rega, B., Delarue, J.,Teillet, E.\&Giampali, P. 2014. Classification of commercial bitter orange essential oils ( Citrusaurantium L.) based on a combination of chemical and sensory analyses of specific odor markers. Journal of Essential Oil Research, 26:254-262.

Divya, P., Jamuna, P.\& Jyothhi, L.A.2016. Antioxidant properties of fresh and processed Citrus aurantium fruit. Cogent Food and Agriculture, 2:1184119http://dx.doi.org/10.1080/23 311932.2016.1184119

Fance, W. J. 1969. Bread Making and Flour Confectionery, $3^{\text {ed }}$ Ed. AVI Publishing co., Westport conn. New York, USA.

Ibrahim, H.M. \& Hamed, A.A.M.2018.Some physicochemical and functional properties of lemon and orange peels. International Journal of Current Microbiology and Applied Sciences, 7:4871-4885

Janati, S.S.F., Beheshti, H.R., Feizy, J. \& Fahim, N.M. 2012.Chemical composition of lemon (Citrus Limon) and peels its considerations as animal food. GIDA The Journal of Food , 37:267-271.

Kadaikunnan,S., Rejiniemon,T.S., Khled,J.M., Alharbi, \& Mothana.2015. In-vitro antibacterial, antifungal, antioxidant and functional properties of Bacillus amyloliquefaciens. . Annals of Clinical Microbiology and Antimicrobials, 14: 1-11
Kamal, G.M., Anwar, F., Hussain, A.I., Sarri, N. \& Ashraf, M.Y.2011. Yield and chemical composition of citrus essential oils as affected by drying pretreatment of peels. International Food Research Journal, 18:1275-1282.

Kammoun, B. A., Ghanem, N., Mihoubi, D., Kechaou, N. \& Boudhrrioua, M. N. 2011. Effect of infrared drying on drying kinetics, color, total phenols, water and oil holding capacities of orange (Citrus sinensis) peel and leaves. International Journal Food Engineering, 7: 5-11.

Kramer, A., \&Twigg, B. A. 1973.Quality Control for the Food Industry $3^{\text {ed }}$ Ed. AVL Publishing Co. Westport conn. London, England PP:132-133.

Lina, N., Satoa, T., Takayamaa, Y., Mimakib, Y., Sashidab, Y., yanoc, M. \& Ito, A.2003. Novel anti-inflammatory actions of nobilrtin, a citrus polymethoxy flavonoid, on human synovial fibroblasts and mouse macrophages. Biochemical pharmacology, 65:2065- 2071.

Lopes, L.M.C., Goncalvesesa, C., de Almeida, A.A., da casta, J.P., Marques, T.H.,\& Feitosa, C.M. 2011. Sedative, anxiolytic and antidepressant activities of citrus lemon (Burn) essential oil in mice. Diepharmazie, 66: 623-627

M'hiri, N., Ioannou, I., Ghoul, M. \& Mihoubi, B. N. 2015. Proximate chemical composition of orange peel and variation of phenols and antioxidant activity during convective air drying. Journal of New Sciences, 9:881-890.

Madhuri, S., Ashwini, u., Srilakshmi, N.S.\& Prashita. Kekuda, T.R. 2014. Journal of Pharmaceutical and Scientific Innovation, 3: 366368.

Minifie, B. W. 1982. Chocolate Cocao and Confectionery, Science and Technology, Avi Publishing Co. Westport conn. Chicago, USA.

Mostafa, B. \& Eid, H.2017.Citrus volkameriana . A potential adjunct herbal extract in mangagement of chronic gingivitis. Current Science International, 3: 506-510.

Nasser, M.A., Bondok, A.Z., shaltout, A.D. \&Mansour, N. 2014. Evauation of some new navel orange cultivars budded on sour orange and volkamer lemon rootstocks. Egyption Journal of Horticulture, 2:239-262.

Olabinjo, O.O., Ogunlowo, A.O., Ajayi, O.O. \& 
Olalusi, A.P.2017. Analysis of physical and chemical composition of sweet orange (Citrus Sinensis) peels. International Journal of Enviroment, Agriculture and Biotechnology, 2:2201-2206.

Oroian, M. \&Escriche, I. 2015. Antioxidants: Characterization, natural sources, extraction and analysis: A Review. Food Research International, 174:10-36.

Plummer, D.T. 1978.An Introduction to Practical Biochemistry. Second Edition McGraw-Hillbook Co UK Limited p. 318.

Rachel, A.R.; Roger, K.B., ysidor, K.\&Henri, B.G.2013. Assessment of physicochemical and mineral characters of orange (Citrus sinnensis) peels. Journal of Asian Scientific Research, 3:1181-1198.

Rafiq, S., Kaul, R., Safi, S.A., Bashir, N., Nazir, F.\&Nayik, G.A.2018. Citrus peel as a source of functional ingredients: A review. Journal of the Saudi Society of Agricultural Sciences, 17:351-358.

Ranganna, S.1977. Manual of Analysis of Fruit and Vegetable Products.Tata McGraw-Hill Publishing Company Limited New Delhi.

Ruch, R.J., Cheng, S.J. \&Klaunig, J.E.1989. Prevention of cytotoxicity and inhibition of intracellular communication by antioxidant catechinns isolated from Chinese green tea. Journal of Carcinogenesis, 10:1003-1008.

SAS 2004.SAS Institute Inc. SAS/ETS ${ }^{\circledR} 9.1$ User'SAS Institute Inc. 2004. User's Guide. Cary, NC.

Sing, B. Panesar, P.S. \& Nada, V. 2006. Utiliza- tion of carrot pomace for the preparation of a value added product. World Journal of Dairy and Food Science, 1:22-27.

Singleton, V.L., Orthofer, R. \& Lamuela-Raventos, R.M. 1974. Analysis of total phenols and other oxidation substrates and antioxidant by means of Folin-Ciocateu reagent. Methods of Enzymology, 299:152-178.

Suntar, I., Khan, H., Patel, S., Celano, R.\& Rastrelli. 2018. An overview on Citrus aurantium L.: Its functions as food Ingredient and Therapeutic agent. Oxidative Medicine and Cellular Longevity.Article ID 7864269, 12 pages https:// doi. Org/10.11ss/2018/7864269.

Suryawanshi, J.A.S.2011. An overview of citrus aurantium used in treatment of various diseases. African Journal of Plant Science, 5: 309-395.

Tee, E.S., Kuladevan, R., Young, S.I., Khor, S.C. \& Zakiyah, H.O. 1996.Nutrient Analysis of Food. Kuala Lumpur: Institute Medical for Research.

Zoair, A.S.,Abou-Garbia, H.A., Attia, R.S. \&Youssef, M.M.2017 utilization of orange, banana and potato peels versus their ethanolic extracts as antioxidants in corn oil. Alexandria Journal of Food Science and Technology, 14:29-39

Zoair, A. S., Attia, R.S., Abo Garbia, H. A. \&Youssef, M. M. 2016.Utilization of orange, banana and potato peels in formulating functional cupcakes and crackers. Alexandria Journal of Food Science \&Technology, 13:11-18. 


\section{دراسات طبيعية و كيماوية و تكنولوجية على ثمار ليهون الفولكا}

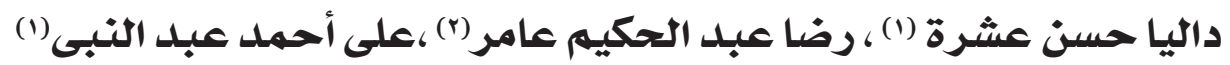
اقسم علوم و تقنية الأغذية - كلية الزراعة - جامعة الاسكندرية- الشاطبى - الشعابـ-

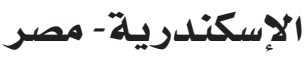

r قسم بحوث تصنيع الحاصلات البستانية - معهد بحوث تكنولوجيا الأغذية - مركز البحوث

$$
\text { الزر اعية- مصر }
$$

نظر العدم وجود معلو مات منشورة عن الخصائص الطبيعية و الكيماوية و التكنولوجية لثمار ليمون الفولكا

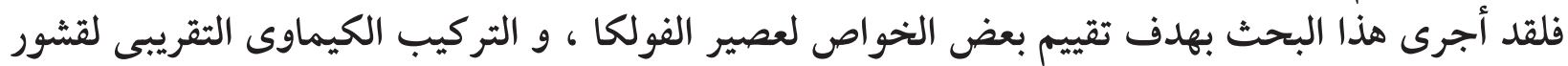

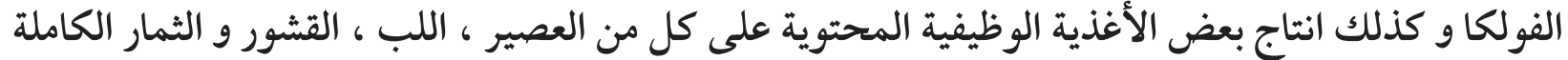

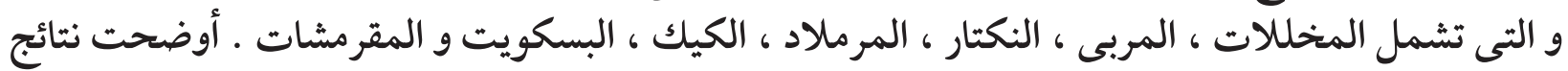

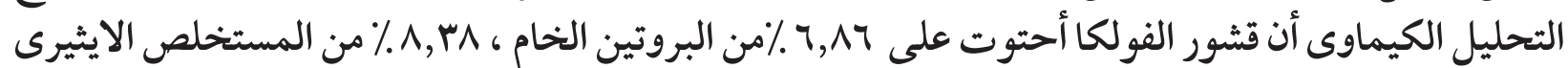

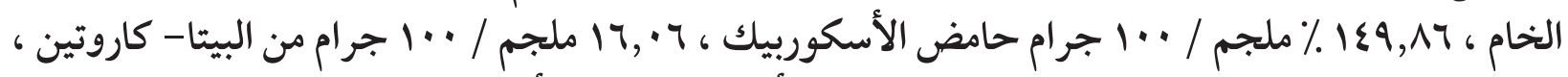

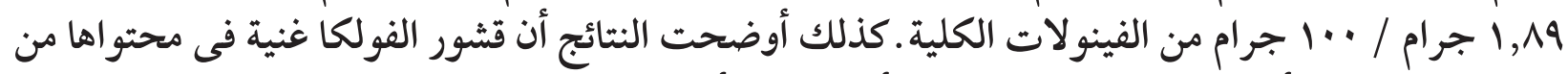

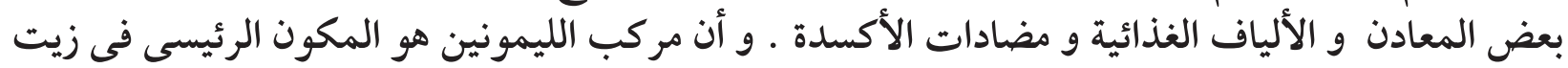

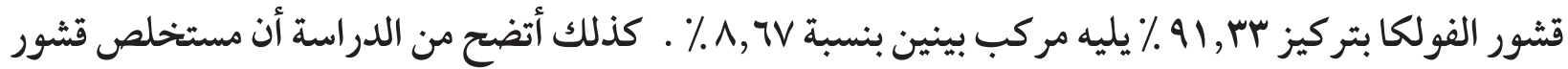

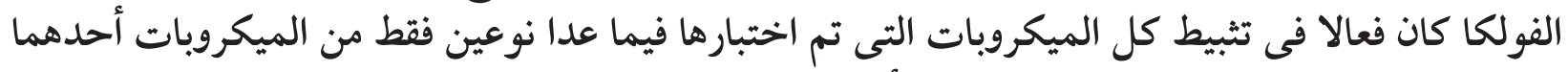

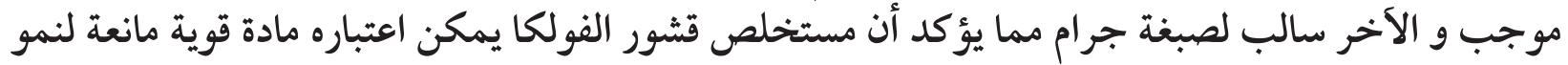

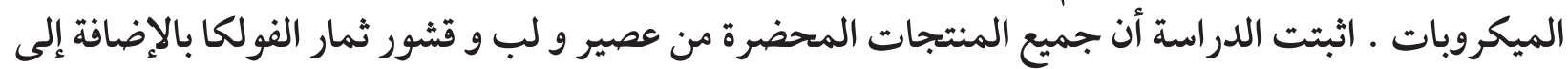
الثمار الكاملة كانت مقبولة من الناحية الحسية . 